\title{
Antifungal activity, antibiofilm, synergism and molecular docking of Allium sativum essential oil against clinical isolates of $C$. albicans
}

Atividade antifúngica, antibiofilme, sinergismo e docking molecular do óleo essencial de Allium sativum contra isolados clínicos de $C$. albicans

Antifúngico, antibiofilm, sinergismo y actividad de acoplamiento molecular del aceite esencial de Allium sativum contra aislados clínicos de $C$. albicans

\begin{abstract}
The aim of the present study was to investigate the biological activity of $A$. sativum essential oil against clinical isolates of $C$. albicans and, in addition, a computational study of the action of two main compounds of the essential oil on the protein of the fungus CYP51 was carried out. The Minimum Inhibitory Concentration and the Minimum Fungicidal Concentration were determined by the broth microdilution method. The biofilm formation was evaluated by biomass quantification using the violet crystal staining method. For the study of molecular docking computer simulations of interaction between CYP51 and ligands were performed using the AutoDock Vina code. The main constituents were diallyl disulfide, followed by diallyl disulfide. The essential oil demonstrated activity against clinical isolates of $C$. albicans. The essential oil showed a reduction progressive increase in the biomass produced from the biofilms of all yeasts tested in this study. The ligands Diallyl disulfide, Diallyl trisulfide and fluconazole formed complexes with the protein target. Based on the results, the essential oil of A. sativum can be considered promising product for the development of new drugs in the prevention of infections associated with $C$. albicans. This study characterizes the effects of A. sativum essential oil against clinical isolates of $C$. albicans responsible for the development of pathologies in humans.
\end{abstract}

Keywords: Pathogenesis; Biofilms; Modelling; Virulence; Mycology. 


\begin{abstract}
Resumo
O objetivo do presente estudo foi investigar a atividade biológica do óleo essencial de A. sativum contra isolados clínicos de $C$. albicans e, além disso, um estudo computacional da ação de dois compostos principais do óleo essencial sobre a proteína do fungo CYP51. A Concentração Inibitória Mínima e a Concentração Fungicida Mínima foram determinadas pelo método da microdiluição em caldo. A formação de biofilme foi avaliada por quantificação de biomassa usando o método de coloração com cristal violeta. Para o estudo de docking molecular, simulações de computador de interação entre CYP51 e ligantes foram realizadas usando o código AutoDock Vina. Os principais constituintes foram dissulfeto de dialila, seguido por dissulfeto de dialila. O óleo essencial demonstrou atividade contra isolados clínicos de C. albicans. O óleo essencial apresentou redução progressiva e aumento da biomassa produzida a partir dos biofilmes de todas as leveduras testadas neste estudo. Os ligantes dissulfeto de dialila, trissulfeto de dialila e fluconazol formaram complexos com a proteína alvo. Com base nos resultados, o óleo essencial de A. sativum pode ser considerado produto promissor para o desenvolvimento de novos fármacos na prevenção de infecções associadas a $C$. albicans. Este estudo caracteriza os efeitos do óleo essencial de A. sativum contra isolados clínicos de C. albicans responsáveis pelo desenvolvimento de patologias em humanos.
\end{abstract}

Palavras-chave: Patogênese; Biofilmes; Modelagem; Virulência; Micologia.

\title{
Resumen
}

El objetivo del presente estudio fue investigar la actividad biológica del aceite esencial de A. sativum frente a aislados clínicos de $C$. albicans y, además, un estudio computacional de la acción de dos compuestos principales del aceite esencial sobre la proteína del hongo CYP51. La Concentración Mínima Inhibitoria y la Concentración Mínima Fungicida se determinaron mediante el método de microdilución en caldo. La formación de biopelículas se evaluó mediante cuantificación de biomasa utilizando el método de tinción con violeta cristal. Para el estudio del acoplamiento molecular, se realizaron simulaciones por computadora de la interacción entre CYP51 y ligandos utilizando el código AutoDock Vina. Los componentes principales fueron disulfuro de dialilo, seguido por disulfuro de dialilo. El aceite esencial demostró actividad contra aislados clínicos de C. albicans. El aceite esencial mostró una reducción progresiva y un aumento de la biomasa producida a partir de las biopelículas de todas las levaduras probadas en este estudio. Los enlazadores de disulfuro de dialilo, trisulfuro de dialilo y fluconazol formaron complejos con la proteína diana. Según los resultados, el aceite esencial de A. sativum puede considerarse un producto prometedor para el desarrollo de nuevos fármacos para prevenir infecciones asociadas con C. albicans. Este estudio caracteriza los efectos del aceite esencial de A. sativum contra aislados clínicos de $C$. albicans responsables del desarrollo de patologías en humanos.

Palabras clave: Patogenia; Biopelículas; Modelado; Virulencia; Micología.

\section{Introduction}

Garlic (Allium sativum L.) is one of the most important vegetables in the world, with a total harvest area of 1,437,690 ha and an annual production of 24,255,303 tons of dry bulbs (FAO, 2013). Commonly used for culinary purposes, garlic is also very popular due to its therapeutic and medicinal properties, both in traditional and modern medicine. Being consumed as a raw vegetable (fresh leaves or dry teeth) or after processing in the form of oil, extract and even significant differences in chemical composition and, consequently, the content of bioactive compounds is observed among the various available garlic formulations (Lanzotti et al., 2014).

The main compounds responsible for the taste and odor of garlic are non-volatile compounds (thiosulfinates) that contain sulfur, among which the aline sulfoxide or S-allyl-cysteine, which are predominant contributors to the taste of garlic (Block et al., 1993; HornícKová et al., 2010). In addition to their flavor attributes, these sulfur compounds are also responsible for the renowned medicinal properties of garlic, such as anticancer, antidiabetic, anti-inflammatory, antimicrobial, antioxidant, cardioprotective and immunomodulatory activities (Alorainy 2011; Chen et al., 2013; Capasso 2013; Kumar et al., 2013; Lanzotti et al., 2014; Borlinghaus et al., 2014). In addition, they can further increase the biosynthesis of glutathione, of which important antioxidant functions are known (Banerjee et al., 2003).

Fungal infections caused by Candida species are emerging as a major health problem, leading to high mortality rates and high medical costs for governments and hospitalized patients. High mortality rates can be attributed to the increasing occurrence of invasive systemic infections and cases of septicemia, especially in immunocompromised patients (Poeta \& Medici 2015; Sakagami et al., 2019). 
C. albicans is the main cause of candidiasis in most clinical situations (Armstrong-James et al., 2017). It is the third microorganism most commonly isolated from bloodstream infections in hospitalized patients (Shields et al., 2012). It is an opportunistic pathogen that resides in oral and conjunctival flora, as well as in the gastrointestinal and genitourinary tracts (Nami et al., 2018).

Cyp51 (Sterol 14 $\alpha$-demethylase) is the single cytochrome P450 (Cyp) required for sterol biosynthesis in different phyla. Among hundreds of P450 proteins, Cyp51 is the only cytochrome P450 protein present in most biological kingdoms including fungi, bacteria, plants and animals. Among azole antifungals, amphotericin B, specifically target the fungal Cyp51, a lanosterol demethylase that is critical for the specific component of the fungal plasma membrane ergosterol biosynthesis (Song \& Zhang 2018). Then, this protein was chosen as target for evaluation the mechanism of action of main constituents of A. sativum essential oil.

Thus, the objective of the present study was to determine the chemical composition of the essential oil of A. sativum, as well as its antifungal activity, antibiofilm and synergistic effect with the antifungal amphotericin B against clinical isolates of $C$. albicans, including also a computational study of the mechanism of action of the main compounds against the enzyme Cyp51 in the ergosterol biosynthesis and inhibition of the enzyme acetylcholinesterase and antioxidant activity.

\section{Methodology}

\subsection{Extraction and chemical characterization}

Bulbs $(1.0 \mathrm{~kg})$ of A. sativum were purchased on the public market in the city of Sobral, CE and in the laboratory were crushed and packed in a $5 \mathrm{~L}$ flask, together with $1.5 \mathrm{~L}$ of water, being then subjected to the hydrodistillation process in Clevenger-type apparatus for a period of $4 \mathrm{~h}$. The oil obtained was dried with anhydrous sodium sulfate $(\sim 1 \mathrm{~g})$, filtered and kept under refrigeration for further analysis.

The chemical composition of the essential oil was determined by gas chromatography analysis using a mass spectrometry detector (CG-EM), performed on a Shimadzu instrument model GC-2010 (quadrupole), with electron impact at $70 \mathrm{eV}$, RTX-5MS methyl polysiloxane column (30 mx $0.25 \mathrm{~mm}$ x $0.25 \mu \mathrm{m}$, Restek), injection mode with 1: 100 flow division, helium carrier gas with 1.00 mL.min-1 flow, injector temperature $250{ }^{\circ} \mathrm{C}$ and ion source at $230{ }^{\circ} \mathrm{C}$. Chromatographic oven programming: initial temperature of $70{ }^{\circ} \mathrm{C}$, with heating ramp from $4{ }^{\circ} \mathrm{C} \cdot \mathrm{min}^{-1}$ to $180{ }^{\circ} \mathrm{C}$ and addition of $10^{\circ} \mathrm{C} / \mathrm{min}$ to $250{ }^{\circ} \mathrm{C}$ at the end of the run $(34.5 \mathrm{~min})$. The identification of the compounds was carried out by analyzing the fragmentation pattern s shown in the mass spectra with those present in the database provided by the equipment (NIST version 2.0 of $2012-243,893$ compounds), calculation of the Retention Index (IR) and data from the literature.

\subsection{Antifungal activity}

In this study, strains from $C$. albicans clinical isolates were used LABMIC 0101 (blood culture), LABMIC 0102 (blood culture), LABMIC 0103 (urine), LABMIC 0104 (tracheal aspirate) and LABMIC 0105 (blood culture), isolated from Santa Casa de Misericordia de Sobral and C. albicans ATCC 90028 used as a standard strain for the analyzes. The entire research was approved by the Ethics Committee of the Universidade Estadual Vale do Acaraú, under the number 644.365.

The isolates were obtained from primary cultures and the yeast strains were presumptively identified according to the morphological characteristics and color of the colonies grown in CHROMagar-Candida medium (Paris, France), as well as in the automated system VITEK 2 (BioMérieux Vitek, Hazelwood, France) and PCR-AGE analysis. The antifungal activity test of essential oil was carried out according to the standards of the Clinical and Laboratory Standards Institute (CLSI 2008a; CLSI 2008b), with some modifications proposed by Fontenelle et al., (2007) and Fontenelle et al., (2008). The fungal strains 
came from the potato agar stock at $-20^{\circ} \mathrm{C}$. They were seeded into tubes containing potato dextrose agar (Difco, Detroit, MI, USA), subsequently incubated at $37{ }^{\circ} \mathrm{C}$. The yeast suspension was obtained by dilution 1: 100 followed by a 1:20 dilution of the standard suspension with liquid medium RPMI 1640, with L-glutamine, without sodium bicarbonate, buffered to $\mathrm{pH} 7.0$ with MOPS (2-[N-morpholino]-propanesulfonic; MPOS 0.165M), in order to result in concentrations of $5.0 \times 10^{2}$ to $2.5 \times 10^{3}$ UFC.mL ${ }^{-1}$.

\subsection{Minimum Inhibitory concentration (MIC) and Minimum fungicidal concentration (CFM)}

The essential oil was prepared with $100 \%$ mineral oil and its concentrations were analyzed between 0.03 to 2.5 $\mathrm{mg} / \mathrm{mL}$, whereas Amphotericin B (Sigma, Chemical Co., USA) was prepared in distilled water. $100 \mu \mathrm{L}$ of sterile RPMI 1640 medium was inoculated into each well of the microdilution plate, followed by $100 \mu \mathrm{L}$ of the test solution added to the first line, from which serial dilutions were made up to line G. Also $100 \mu \mathrm{L}$ of the suspension was added fungal in all wells. The fungal growth control wells presented $100 \mu \mathrm{L}$ of sterile medium, free of drugs and oil, added with $100 \mu \mathrm{L}$ of the inoculum suspensions. The plates were incubated at $37{ }^{\circ} \mathrm{C}$ for 24 hours, after which the plates were visually read, observing the macroscopic reduction of fungal growth. MIC was defined by the smallest test fraction capable of inhibiting visually detected fungal growth. CFM corresponded to the lowest concentration that resulted in fungal death after $24 \mathrm{~h}$ with the sowing of 100 $\mu \mathrm{L}$ of solution from wells without turbidity on potato dextrose agar.

\subsection{Biofilm and preformed biofilm formation inhibition test}

The test was carried out based on serial microdilution tests and violet crystal staining in 96-well polyethylene plates according to Stepanovic et al., (2000), with modifications. The preparation of the plates for the tests was similar to the procedure used in the MIC test. Strains of C. albicans LABMIC 0101, LABMIC 0102 and LABMIC 0104 were used. To evaluate the action of essential oil on preformed biofilms, each well of the polystyrene plate was filled with $100 \mu \mathrm{L}$ of the yeasts plus $100 \mu \mathrm{L}$ of sterile RPMI 1640 in suspension at a concentration of $2 \times 10^{6}$ UFC.mL- 1 and incubated at $37{ }^{\circ} \mathrm{C}$ for $24 \mathrm{~h}$. After the incubation time, the supernatant was removed and replaced with $200 \mu \mathrm{L}$ of medium with oil in different concentrations for another $24 \mathrm{~h}$ at $37^{\circ} \mathrm{C}$.

\subsection{Quantification of biomass}

The quantification of biofilm biomass was determined using the violet crystal (CV) staining method. After 24 hours of incubation, the plates were washed with sterile distilled water three times to remove non-adhered planktonic cells. Subsequently, the wells were filled with $200 \mu \mathrm{L}$ of methanol for 5 minutes to fix the biofilms. Then, $200 \mu \mathrm{L}$ of $1 \%$ violet crystal was added for another 5 minutes. Then, the excess dye was removed and the plates washed with distilled water. The remaining dye was removed with $33 \%$ acetic acid and then the biomass was quantified by measuring the optical density at $590 \mathrm{~nm}\left(\mathrm{DO}_{590}\right)$ with the aid of a microplate reader.

\subsection{Antioxidant activity}

The antioxidant activity was measured in 96-well flat-bottom plates using the Elisa BIOTEK reader, model ELX 800, software "Gen5 V2.04.11", based on the methodology described by Becker et al., (2019). The following solutions were used per well: $180 \mu \mathrm{L}$ of methanolic solution of DPPH (2,2-diphenyl-1-picrilhidrazil), $20 \mu \mathrm{L}$ of the essential oil sample dissolved in methanol and diluted 10 times to obtain a final concentration of $0.2 \mathrm{mg} . \mathrm{mL}^{-1}$. 
The dilutions of the samples and the positive standards used in the quantitative microplate evaluations, departing from the mother solution with a concentration of $20 \mathrm{mg} / \mathrm{mL}$ were: $200 \mu \mathrm{g} \cdot \mathrm{mL}^{-1}, 100 \mu \mathrm{g} \cdot \mathrm{mL}^{-1}, 50 \mu \mathrm{g} \cdot \mathrm{mL}^{-1}, 25 \mu \mathrm{g} \cdot \mathrm{mL}^{-1}, 12.5 \mu \mathrm{g} \cdot \mathrm{mL}^{-1}$, $6.25 \mu \mathrm{g} \cdot \mathrm{mL}^{-1}, 3.12 \mu \mathrm{g} \cdot \mathrm{mL}^{-1}, 1.56 \mu \mathrm{g} \cdot \mathrm{mL}^{-1}$, and $0.78 \mu \mathrm{g} \cdot \mathrm{mL}^{-1}$.

Absorbance was measured at $490 \mathrm{~nm}$ until a total of 60 minutes of incubation. As a negative standard, all solutions were used, except for the sample. The values referring to the natural colorings of the extracts were extinguished from the analysis. The percentage of inhibition (PI\%) was calculated by comparing the reaction rates of the samples in relation to the controls. The standard used as a positive control is quercetin. All samples were analyzed in triplicate.

The results expressed as a percentage of inhibition, calculated with the following formula:

$$
P I \%=\frac{A C-A S}{A C} \times 100
$$

AC: Absorbance of DPPH control at 0h time

AS: Absorbance of the sample containing DPPH at 60 min

\subsection{Inhibition of the enzyme acetylcholinesterase}

The inhibitory activity of the acetylcholinesterase enzyme (AChE) was measured in 96-well flat-bottom plates using an Elisa BIOTEK reader, model ELX 800, software "Gen5 V2.04.11", based on the methodology described by Ellman et al. (1961). In 96-well plates, the following solutions were used per well: $25 \mu \mathrm{L}$ of acetylthiocholine iodide $(15 \mathrm{mM}), 125 \mu \mathrm{L}$ of 5.5' - dithiobis- [2-nitrobenzoic] in the Tris / HCL solution (50nM, pH = 8, with 0.1 M NaCL and 0.02 M MgCL2 .6H2O. (3 $\mathrm{mM}, \mathrm{DTNB}$ or Ellman's reagent)), $50 \mu \mathrm{L}$ of the Tris/HCL solution $(50 \mathrm{nM}, \mathrm{pH}=8$, with $0.1 \%$ bovine serum albumin (BSA)), $25 \mu \mathrm{L}$ of the essential oil sample dissolved in methanol and diluted 10 times in the Tris / HCL solution $(50 \mathrm{mM}, \mathrm{pH}=8)$ to obtain a final concentration of $0.2 \mathrm{mg} \cdot \mathrm{mL}^{-1}$ (Rhee et al., 2001; Trevisan et al., 2003).

Absorbance was measured at $405 \mathrm{~nm}$ for 30 seconds. Then, $25 \mu \mathrm{L}$ of the enzyme acetylcholinesterase $(0.25 \mathrm{U} . \mathrm{mL}-1)$ was added and the absorbance was measured per minute until the total of 25 minutes of enzyme incubation. As a negative standard, all solutions were used, except for the sample and as a positive control, physostigmine (eserine). The percentage of acetylcholinesterase inhibition was calculated by comparing the reaction rates (substrate hydrolysis) of the samples in relation to the blank (considered total AChE activity, 100\%). All samples were analyzed in triplicate and the data were normalized using the statistical program GraphPad Prism v5.01.

\subsection{Synergism with antifungals}

The effect of the essential oil of A. sativum combined with the antifungal Amphotericin B was determined by the checkerboard technique, this method being used to determine the interaction of drugs by calculating the Fractional Inhibitory Concentration Index (ICIF). The ICIF is calculated by adding the Fractional Inhibitory Concentration (FIC) for each compound tested, being defined as the addition of the MIC values of each drug in the combination and MIC of the same product alone (WHITE et al., 1996). Strains of C. albicans LABMIC 0101, LABMIC 0102, LABMIC 0104, LABMIC 0105 and ATCC 90028 were used.

In the solutions, the products tested were used in the concentrations of their respective MIC values. Initially $50 \mu \mathrm{L}$ of the RPMI medium was added to all 96 wells of the microdilution plate. Then, $50 \mu \mathrm{L}$ of the essential oil diluted in tween 80 $0.02 \%$ was added to the first line and the serial dilution was performed vertically. In the first column, $50 \mu \mathrm{L}$ of each antifungal were placed in different concentrations according to the MIC. 
Finally, $100 \mu \mathrm{L}$ of the inoculum was placed in all wells. The RMPI medium with the inoculum was used as a negative control. The plates were incubated at $37^{\circ} \mathrm{C}$ for $24 \mathrm{~h}$. According to the results obtained, ICIF values $\leq 0.5$ will be indicative of synergistic effect, ICIF values $>0.5$ and $\leq 1.0$ will be indicative of additive effects and ICIF values $>1.0$ will be indicative of effect antagonistic (Lechartier, Hartkoorn \& Cole 2012; Rosato et al., 2007).

\subsection{Molecular docking with CYP51 and 4EY6 enzymes}

The structure of proteins CYP51 and 4EY6 were obtained from the Protein Data Bank database (https://www.rcsb.org/). For molecular docking simulations, proteins were prepared by removing all residues and adding polar hydrogens (Schimmel et al., 1998), producing favorable protonation states for the simulations (Milite et al., 2019).

The CYP51 protein was identified in the repository as "Structure of CYP51 from the pathogen Candida albicans" (PDB 5V5Z). The structure of CYP51 is deposited in Protein Data Bank with a resolution of $2.90 \AA$, determined by X-ray diffraction (R-Value Free: 0.269, R-Value Work: 0.219), classified as oxidoreductase, Candida albicans SC5314 organism and expression Saccharomyces cerevisiae.

For the 4EY6 protein it was identified in the repository as "Crystal Structure of Recombinant Human Acetylcholinesterase in Complex with (-) - galantamine" (PDB 4EY6). The structure of 4EY6 is deposited in the Protein Data Bank with a resolution of $2.40 \AA$, determined by X-ray diffraction (R-Value Free: 0.206, R-Value Work: 0.167), classified as hydrolase / hydrolase inhibitor, organism and system of expression Homo sapiens.

For the computational study of molecular docking, the two major compounds of the essential oil of A. sativum were selected: Diallyl disulfide (content of 48.24\%) and Diallyl trisulfide (content of 33.73\%). As reference drugs, the itraconazole inhibitor (1YN) was used, which is complexed with the enzyme (PDB 5V5Z) (Keniya et al., 2018) and fluconazole, one of the main antifungals used for Candida spp. (Sueth-Santiago et al., 2015) For anticholinesterase activity, (-) - Galanthamine was used. The ligands must be in their best potential energy state for the simulations; therefore, they were optimized by the semiempirical parametric method 7 (PM7) (Stewart 2013; Almeida-Neto et al., 2020) using the MOPAC® software.

For the study of molecular docking, computer simulations of interaction between proteins and ligands were performed using the AutoDock Vina code (version 1.1.2), using 3-way multithreading, Lamarkian Genetic Algorithm (Trott and Olson, 2009), with docking parameters: center_x $=-45,642$, center_y $=-14,402$, center_z $=22,495$, size $\_x=126$, size_y $=90$, size_z $=102$, spacing $=0.642$. The grid box parameters were configured to fit the whole protein, seeking greater amplitude in the selection of poses. 100 independent simulations were carried out for all protein targets, obtaining 10 poses each, as a standard procedure.

For the selection of the simulations with the best poses, the simulations with RMSD (Root Mean Square Deviation) value less than $2 \AA$ were used as criteria. (Yusuf et al., 2008; Shityakov and Förster, 2014) To analyze the results and generate two-dimensional maps of chemical interactions, the Discovery Studio Visualizer (Biovia et al., 2000) and UCSF Chimera codes were used. (Pettersen et al., 2004)

\subsection{Statistical analysis}

All tests were performed in triplicates and with a significance level of $p<0.05$. For the tests, the difference between the means of the triplicates was verified through the application of the One-way ANOVA test with Bonferroni post-test, performed with the aid of the GraphPad Prism version 8.0 for Windows (San Diego, California, USA). 


\section{Results and Discussion}

In this study, the in vitro susceptibility as well as the antibiofilm activity of different strains of $C$. albicans obtained from clinical isolates with the essential oil of A. sativum and amphotericin B was evaluated. The chemical composition of the essential oil of A. sativum and the respective percentages are reported in Table 1 . The essential oil yield was $0.8 \%$ (w/w) dry weight. The essential oil contained 08 components, including mono and sesquiterpenes, representing $98.85 \%$ of the respective oil. The main constituents were diallyl disulfide (48.24\%), followed by diallyl disulfide (33.73\%). The chemical structures are shown in Figure 1.

Table 1. Chemical composition of A. sativum essential oil.

\begin{tabular}{c|c|c|c}
\hline Compound & ${ }^{\mathbf{2}} \mathbf{I R}_{\text {calc }}$ & ${ }^{\mathbf{3}} \mathbf{R}_{\text {lit }}$ & Teor (\%) \\
\hline 1,2-Dithiolane & 844 & 842 & 0.14 \\
Diallyl sulfide & 857 & 855 & 2.70 \\
Allyl methyl disulfide & 919 & 916 & 5.08 \\
Dimethyl trisulfide & 975 & 968 & 0.32 \\
Diallyl disulphide & 1083 & 1080 & 48.24 \\
Allyl methyl trisulfide & 1142 & 1138 & 7.05 \\
Diallyl trisulfide & 1305 & 1301 & 33.73 \\
Diallyl tetrasulfide & 1545 & 1540 & 1.59 \\
\hline Total Composition & & 98.85 \\
\hline
\end{tabular}

${ }^{1}$ Calculated IR values. ${ }^{2}$ Literature IR values. Source: Authors.

Fasihzadeh et al., (2016) reported that the extraction efficiency of the essential oil of $A$. sativum was 0.06 (v/v) and the main compounds were 1-butene, 1-(methylthio) - (Z) (18.21\%), methyl methylthiomethyl disulfide (8.41\%), dimethyl tetra sulfide $(6.47 \%)$ and piperitenone oxide $(4.55 \%)$ were the most abundant components and constituted $37.64 \%$ of the essential oil, while 2,5-diethylthiophene $(0.07 \%)$ and n-Nonanal $(0.06 \%)$ were detected in smaller quantities. The presence of compounds showed mono-sulfur compounds (22.42\%), disulfide (1.81\%), tri-sulfur (13.57\%) and tetra-sulfur (6.47\%). The results indicated that the highest amount of sulfur compounds is related to monosulfur compounds. Differences in the sulfur content of the constituents of this plant were observed with other species of the genus Allium.

Figure 1. Structural representation of the main constituents of the essential oil of A. sativum Diallyl disulphide (1) and Diallyl trisulfide (2).<smiles>C=CCSSCC=C</smiles><smiles>C=CCSSSCC=C</smiles> 
Behbahani and Fooladi (2017) reported that the essential oil of A. sativum has 14 compounds, with a total of $96.5 \%$ of the composition. 5-chloroacetaldehyde was the main compound (45.6\%), as well as methylthiomethyl disulfide (28.2\%), pentiophene $(5.4 \%)$, tricosane $(5.2 \%)$, dimethyl trisulfide (4, 5\%), carvacrol (1.2\%) and thymol (0.5\%). Mahboubi et al., (2014) reported that the oil extraction efficiency was $0.04(\mathrm{v} / \mathrm{v})$, and consisted of 5-chloroorcilaldehyde (55.1\%), methylmethylthiomethyl disulfide (24.6\%), Tricosan $(6.3 \%)$, pentylthiophene $(3.8 \%)$ and dimethyl trisulfide $(3.1 \%)$.

Regarding the in vitro antifungal activity of the essential oil of A. sativum, the results presented in Table 2 shows that the essential oil was able to inhibit the microbial growth of $C$. albicans ranging from 1.25 to $0.625 \mathrm{mg}^{\mathrm{m}} \mathrm{mL}^{-1}$. Regarding the CFM results, the essential oil showed activity against C. albicans 0101, C. albicans 0102 and C. albicans 0104 at a concentration of $2.5 \mathrm{mg}$. $\mathrm{mL}^{-1}$ and in C. albicans 0103, C. albicans 0105 and C. albicans ATCC 90028 at a concentration of $1.25 \mathrm{mg} . \mathrm{mL}^{-1}$. In relation to amphotericin $\mathrm{B}$ and fluconazole, the concentration was $1 \mu \mathrm{g} . \mathrm{mL}^{-1}$.

Previous reports have Origin Blood culture Tracheal aspirate demonstrated the antifungal activity of allicin, a compound present in the essential oil of A. sativum, in vitro against Aspergillus, Trichophyton and Candida spp. (Yamada \& Azuma 1977; Aala et al., 2010). Allicin exhibited antifungal activity with MIC between 0.195 and $6.25 \mu \mathrm{g} / \mathrm{ml}$ and, when used in synergy with antimicrobial agents, increases the effectiveness of therapeutic agents (Aala et al. 2010; Khodavandi et al. 2010). For example, the combination of allicin with amphotericin B and fluconazole has been shown to have a significant synergistic effect in a model of systemic candidiasis in mice (An et al., 2009; Guo et al., 2010).

Table 2. Minimum Inhibitory Concentration (MIC) and Minimum Fungicide Concentration (MFC) of the essential oil against C. albicans species.

\begin{tabular}{|c|c|c|c|c|c|}
\hline \multirow[t]{2}{*}{ C. albicans } & \multirow[t]{2}{*}{ Origin } & \multicolumn{2}{|c|}{ Essential oil } & AMB & FLC \\
\hline & & $\begin{array}{c}\text { MIC } \\
\mathrm{mg} \cdot \mathrm{mL}^{-1}\end{array}$ & $\begin{array}{c}\text { MFC } \\
\text { mg. } \mathrm{mL}^{-1}\end{array}$ & $\begin{array}{c}\text { MIC } \\
\mu \mathrm{g} \cdot \mathrm{mL}^{-1}\end{array}$ & $\begin{array}{c}\text { MIC } \\
\mu \mathrm{g} . \mathrm{mL}^{-1}\end{array}$ \\
\hline LABMIC 0101 & Blood culture & 1.25 & 2.5 & 1.0 & 1.0 \\
\hline LABMIC 0102 & Blood culture & 1.25 & 2.5 & 1.0 & 1.0 \\
\hline LABMIC 0103 & Urine & 0.625 & 1.25 & 1.0 & 1.0 \\
\hline LABMIC 0104 & Tracheal aspirate & 1.25 & 2.5 & 1.0 & 1.0 \\
\hline LABMIC 0105 & Blood culture & 0.625 & 1.25 & 1.0 & 1.0 \\
\hline ATCC 90028 & Culture Collection & 0.625 & 1.25 & 1.0 & 1.0 \\
\hline
\end{tabular}

LABMIC- Microbiology Laboratory; ATCC- American Type Culture Collection; AMB- amphotericin B; FLC- Fluconazole Source: Authors.

Essential oils can penetrate the plasma membrane due to their lipophilic characteristics. Li et al., (2016) observed in transmission electron microscopy that some organelles, such as mitochondria and vacuoles, were damaged in $C$. albicans cells after treatment with A. sativum essential oil, indicating that the essential oil could penetrate the membranes of organelles. A. sativum and some of its derivatives destroy the integrity of the Candida cell membrane (Low et al., 2008), inhibit growth (Lemar et al., 2002) and produce oxidative stress (Lemar et al., 2005) in C. albicans.

Most of these abilities are related to a potential for modification, because the activated disulfide bond of allicin affects thiol-containing compounds, such as some proteins; however, the main targets of allicin in Candida are not well known. It has been shown that the antifungal activity of allicin in vivo can be related to other secondary metabolites, such as ajoene, diallyl trisulfide and diallyl disulfide, because the chemical structure of allicin is very unstable and immediately converts to these products (Miron et al., 2004; Khodavandi et al., 2010). The antifungal properties of the Allium genus have been mentioned in some studies. Shams-Ghahfarokhi et al., (2007) reported that aqueous extracts of $A$. cepa and A. sativum showed antifungal 
activity against Malassezia furfur, Candida spp. and several strains of various species of dermatophytes in a dose-dependent manner, with a maximum of $100 \%$ in defined concentrations. Another study by Amin and Kapadnis (2005) confirmed the antifungal activity of Allium ascalonicum against 23 strains of fungi, among them, C. albicans.

In determining the antimicrobial activity of essential oils, the investigation of their components, as well as the lipophilic nature of their hydrocarbon skeletons and the hydrophilic nature of their functional groups is of fundamental importance (Vieira et al., 2014). A. sativum has been used as a treatment for several diseases since antiquity (Mota et al., 2005) and some more recent studies have found positive results of its antibacterial, antifungal, antiviral, antiprotozoal and anthelmintic action (Venturoso et al., 2011; Lima et al., 2011; Mantawy et al., 2011).

The present study brought evidence that the essential oil has an inhibitory effect on microbial development, a fact also confirmed by other studies (Venturoso et al., 2011; Silva et al., 2012; Cohain 2010; Casella et al., 2012). This evidence indicates that the essential oil of $A$. sativum can be considered an alternative for the treatment of infections caused by yeast.

Scientific studies related to the antibiofilm activity of the essential oil of A. sativum against $C$. albicans are rarely reported in the literature. As shown in figure 2 on the inhibition of biofilm formation, the essential oil significantly reduced the biofilm biomass of all yeasts tested in this study. Concentrations ranged from 2.5 to $0.039 \mathrm{mg}$. $\mathrm{mL}^{-1}$ in which the essential oil reduced the amount of biomass to values between 60 and 96\%. Regarding the biomass quantification of preformed biofilms, as shown in Figure 3, there was a 70 to $90 \%$ reduction in the biofilm of $C$. albicans LABMIC 0101 and from 13 to $46 \%$ for $C$. albicans LABMIC 0104. Already for C. albicans LABMIC 0102 there was no significant reduction.

Another study reported that the aqueous extract of A. sativum had inhibitory properties in C. albicans (Li et al. 2015). The extract's antifungal mechanisms mainly include the ability to penetrate the cell membrane, destroy the cell structure and alter the gene expression of microrganisms (Li et al., 2016). The studies by Zainal et al., (2020) showed that allicin exhibited excellent antimicrobial activity against $C$. albicans with an MIC of $8 \mu \mathrm{g} / \mathrm{mL}$ and MFC of $16 \mu \mathrm{g} / \mathrm{mL}$.

The antibiofilm efficacy of allicin against $C$. albicans biofilm is confirmed in the studies by Zainal et al., (2020) because the compound dispersed significantly $(p<0.001)>50 \%$ of the biofilm after exposure to the compound. The treatments in varying concentrations of A. ursinum and A. oschaninii extract in mono- and polymicrobial biofilms of $K$. pneumoniae ATCC 10031 and C. albicans ATCC 90028 showed a significant reduction. Extracts at 50 $\mu \mathrm{g} / \mathrm{mL}$ significantly inactivated all biofilms on both surfaces, compared to the control $(p<0.05)$. A maximum reduction of $7 \log _{10}{ }^{-1} \mathrm{CFU} / \mathrm{cm}^{2}$ was obtained at the highest concentration used in the experiment $(75 \mu \mathrm{g} / \mathrm{mL})$ (Galdiero et al., 2020).

The antioxidant potential of the essential oil was investigated by the free radical scavenging DPPH (1,1-diphenyl-2picrilhidrazil). The $\mathrm{IC}_{50}$ values are shown in Table 3. The essential oil showed antioxidant capacity in the DPPH radical scavenging test, with an $\mathrm{IC}_{50}$ value of $22.18 \mu \mathrm{g} / \mathrm{mL}$. For quercetin (positive control), it presented an $\mathrm{IC}_{50} \mathrm{of} 1.05 \mu \mathrm{g} / \mathrm{mL}$. Table 3 shows the results of AChE inhibition by quantitative assay. The essential oil of A. sativum showed IC50 $12.50 \pm 0.05 \mu \mathrm{g} / \mathrm{mL}$. The samples showed a result close to that found for physostigmine (positive control), which showed $1.15 \pm 0.05 \mu \mathrm{g} / \mathrm{mL}$. 
Figure 2. Antimicrobial effect of the essential oil of A. sativum in different concentrations on the biomass inhibition of $C$. albicans biofilms.
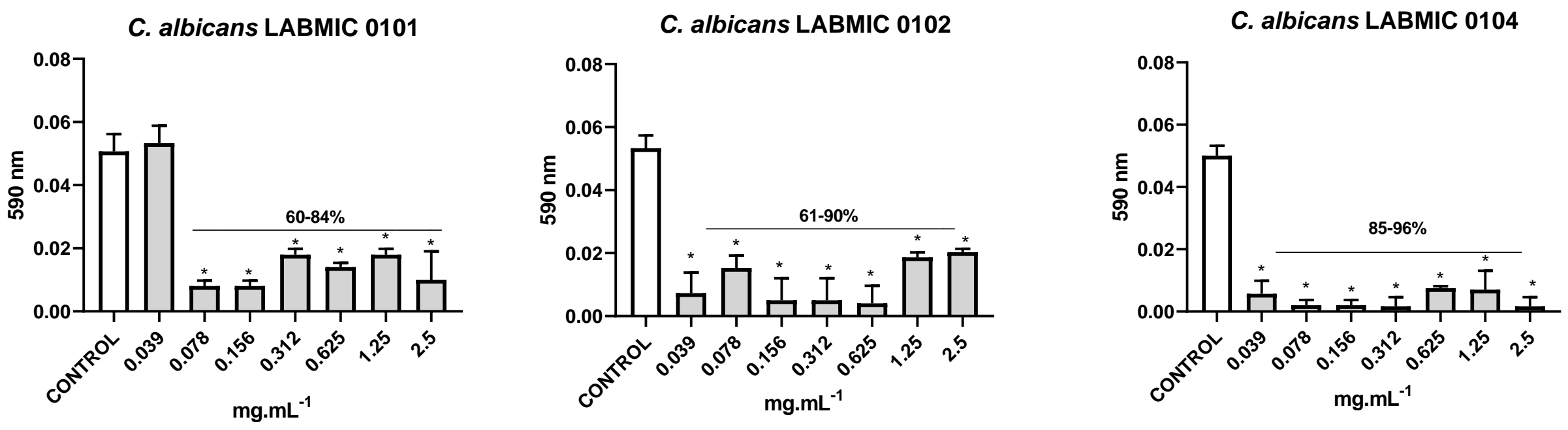

Source: Authors. 
Figure 3. Antimicrobial effect of the essential oil of A. sativum in different concentrations on the biomass inhibition of preformed C. albicans biofilms.

\section{C. albicans LABMIC 0101}

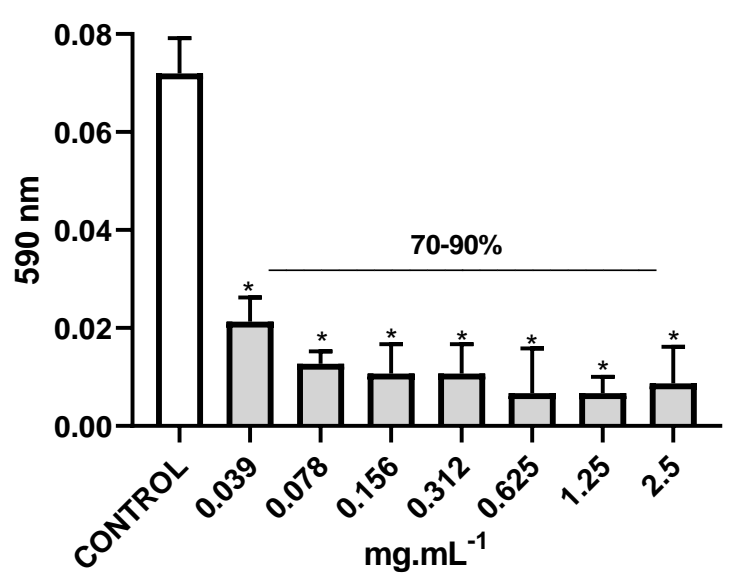

C. albicans LABMIC 0102

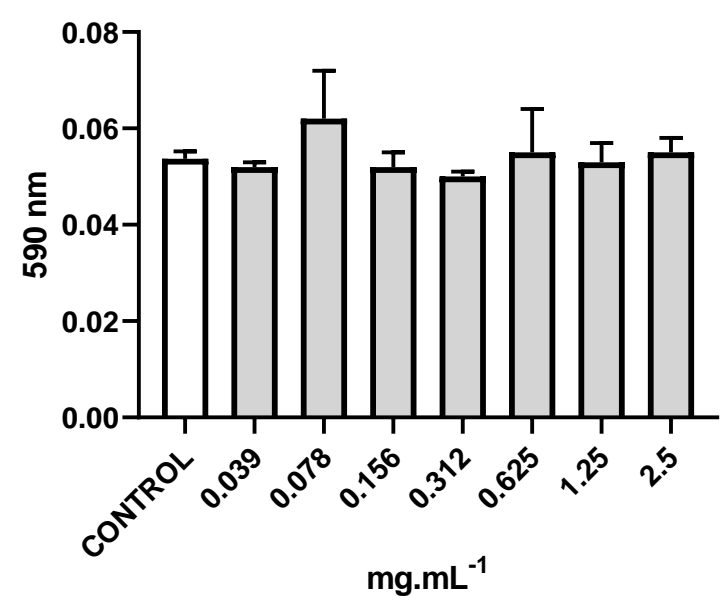

Source: Authors.

\section{C. albicans LABMIC 0104}

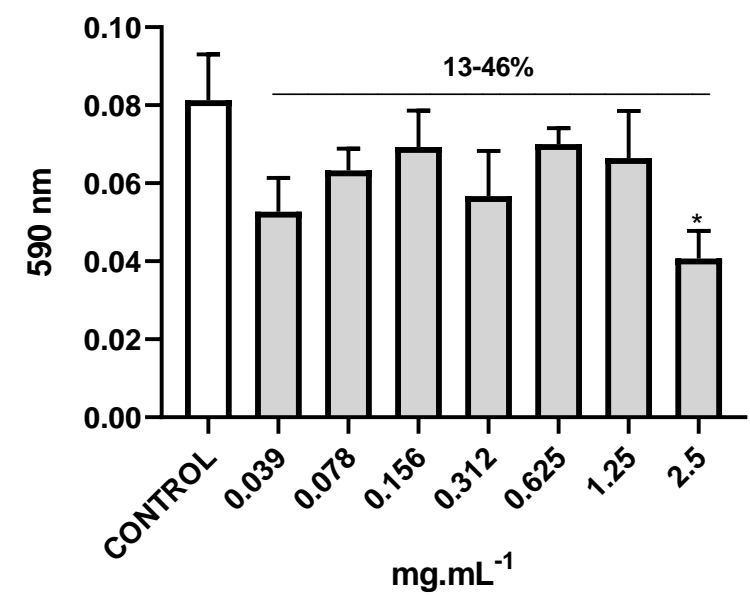


Table 3. Antioxidant activity and inhibition of the enzyme acetylcholinesterase from the essential oil of A. sativum.

\begin{tabular}{lcccc}
\hline & \multicolumn{2}{c}{ DPPH } & \multicolumn{2}{c}{ AChE } \\
$\mathrm{IC}_{50}$ & Quercetin & Essential oil & FISO & Essential oil \\
Std. Error & 1.05 & 22.18 & 1.15 & 12.50 \\
$R$ square & 0.55 & 0.12 & 0.05 & 0.05 \\
& - & - & 0.99 & 0.99 \\
\hline
\end{tabular}

Source: Authors.

The DPPH radical scavenging assay is commonly used to assess the antioxidant activity of more polar compounds, such as phenols and flavonoids (David et al., 2007; Alves et al., 2010). Bioactive molecules that inhibit AChE have therapeutic benefits due to the ability to penetrate the blood-brain barrier, increasing the levels of endogenous acetylcholine, a useful property in the therapy of Alzheimer's disease (Morais et al., 2017).

The combination of antimicrobial agents can be used to increase the spectrum of action, to prevent the emergence of resistant mutants and to promote synergism between two or more drugs. When portraying the synergistic activity, the results are shown in table 4. The combination test of essential oil with the standard antifungal agent amphotericin B showed that there was a reduction in MIC values in all tested strains and also in the strains CIMs of antifungals. From the values, it was possible to calculate the fractional inhibitory concentration index (FICI) which showed a synergistic effect for all strains tested.

Table 4. Determination of FIC indices (FICI) for Candida albicans and amphotericin B.

\begin{tabular}{|c|c|c|c|c|c|c|}
\hline & & & e: Authors. & & & \\
\hline \multirow[t]{3}{*}{ C. albicans } & \multicolumn{2}{|c|}{ Essential oil } & \multicolumn{2}{|c|}{ Amphotericin B } & \multirow[t]{3}{*}{ FICI } & \multirow[t]{3}{*}{ EFFECT } \\
\hline & $\mathrm{MIC} \mu \mathrm{g} / \mathrm{mL}$ & $\mathrm{MIC} \mu \mathrm{g} / \mathrm{mL}$ & $\mathrm{MIC} \mu \mathrm{g} / \mathrm{mL}$ & $\mathrm{MIC} \mu \mathrm{g} / \mathrm{mL}$ & & \\
\hline & (Individual) & (Combined) & (Individual) & (Combined) & & \\
\hline LABMIC 0101 & 1.25 & 0.078 & 1.0 & 0.0078 & 0.070 & Synergism \\
\hline LABMIC 0102 & 1.25 & 0.078 & 1.0 & 0.0078 & 0.070 & Synergism \\
\hline LABMIC 0104 & 1.25 & 0.078 & 1.0 & 0.0078 & 0.070 & Synergism \\
\hline LABMIC 0105 & 0.625 & 0.039 & 1.0 & 0.0009 & 0.063 & Synergism \\
\hline ATCC 90028 & 0.625 & 0.156 & 1.0 & 0.0078 & 0.257 & Synergism \\
\hline
\end{tabular}

Source: Authors.

In view of the antifungal activity of the essential oil of $A$. sativum demonstrated in the present work and several other studies (Venturoso et al., 2011; Silva et al., 2012; Lima et al., 2011; Cohain 2010; Casella et al., 2012), we sought to perform a computational study by molecular docking of the CYP51 protein of C. albicans with the two major compounds of A. sativum oil: Diallyl disulfide and Diallyl trisulfide, as possible pharmacological tools in the treatment of fungal infections.

Molecular docking is essential for understanding the interaction between receptor and ligand, so, after docking, all simulations of ligands showed an RMSD value within the ideal parameter, less than $2 \AA$. (Yusuf et al., 2008) Diallyl disulfide had an RMSD value of 1,151 A, Diallyl trisulfide was 1,965 ̊and Fluconazole was 1,683 $\mathrm{A}$ (Table 5). 
Research, Society and Development, v. 10, n. 12, e313101220457, 2021

(CC BY 4.0) | ISSN 2525-3409 | DOI: http://dx.doi.org/10.33448/rsd-v10i12.20457

Table 5. Interaction energy and RMSD in molecular docking assay with CYP51.

\begin{tabular}{ccc}
\hline \multirow{2}{*}{ Ligands } & \multicolumn{2}{c}{ CYP51 } \\
\cline { 2 - 3 } & Energy & RMSD \\
\hline Diallyl disulfide & -4.2 & 1.151 \\
Diallyl trisulfide & -4.1 & 1.965 \\
Fluconazole & -6.7 & 1.683 \\
\hline
\end{tabular}

Source: Authors.

The ligands Diallyl disulfide, Diallyl trisulfide and fluconazole formed complexes with the protein target, with interaction distances varying between 2.58 and $4.84 \AA$ (Table 6) and binding energy $-4.2 \mathrm{kcal} / \mathrm{mol},-4.1 \mathrm{kcal} / \mathrm{mol}$ and -6.9 kcal/mol respectively. Diallyl disulfide showed a $3.73 \AA$ hydrophobic interaction with the ILE131 residue. Diallyl trisulfide showed only hydrophobic interactions with CYP51, ranging from 3.76 to $3.96 \AA$, with residues ILE131, TYR 132 and THR311. Fluconazole showed interactions with residues LEU87, PRO230, PHE 233 and TYR64.

Table 6. Interactions between CYP51 and major compounds of A. sativum essential oil.

\begin{tabular}{|c|c|c|c|}
\hline Ligand & Receptor & Interaction & Distance $(\AA)$ \\
\hline Diallyl disulfide & *ILE131A & Hydrophobic & 3.73 \\
\hline \multirow[t]{3}{*}{ Diallyl trisulfide } & *ILE131A & Hydrophobic & 3.96 \\
\hline & *TYR132A & Hydrophobic & 3.86 \\
\hline & THR311A & Hydrophobic & 3.76 \\
\hline \multirow[t]{5}{*}{ Fluconazole } & LEU87A & Hydrophobic & 3.22 \\
\hline & *PRO230A & Hydrophobic & 3.45 \\
\hline & PHE233A & Hydrophobic & 3.64 \\
\hline & TYR64A & H-Bond & 2.58 \\
\hline & PHE233A & $\pi$-stacking & 4.84 \\
\hline
\end{tabular}

Legend: * Residues belonging to the itraconazole inhibitor catalytic site. Source: Authors.

Regarding the co-crystallized inhibitor, the two ligands under study coupled in the region of the itraconazole catalytic site (Figure 4), with Diallyl disulfide showing a hydrophobic interaction with the ILE131 residue. Diallyl trisulfide showed two hydrophobic interactions with residues ILE131 and TYR132 from the catalytic site of the enzyme. Fluconazole has only a hydrophobic interaction with residue from the active site (PRO230), coupling in a different region from the other ligands (Figure 5). 
Research, Society and Development, v. 10, n. 12, e313101220457, 2021

Figure 4. Binding site of the compounds under study at CYP51.

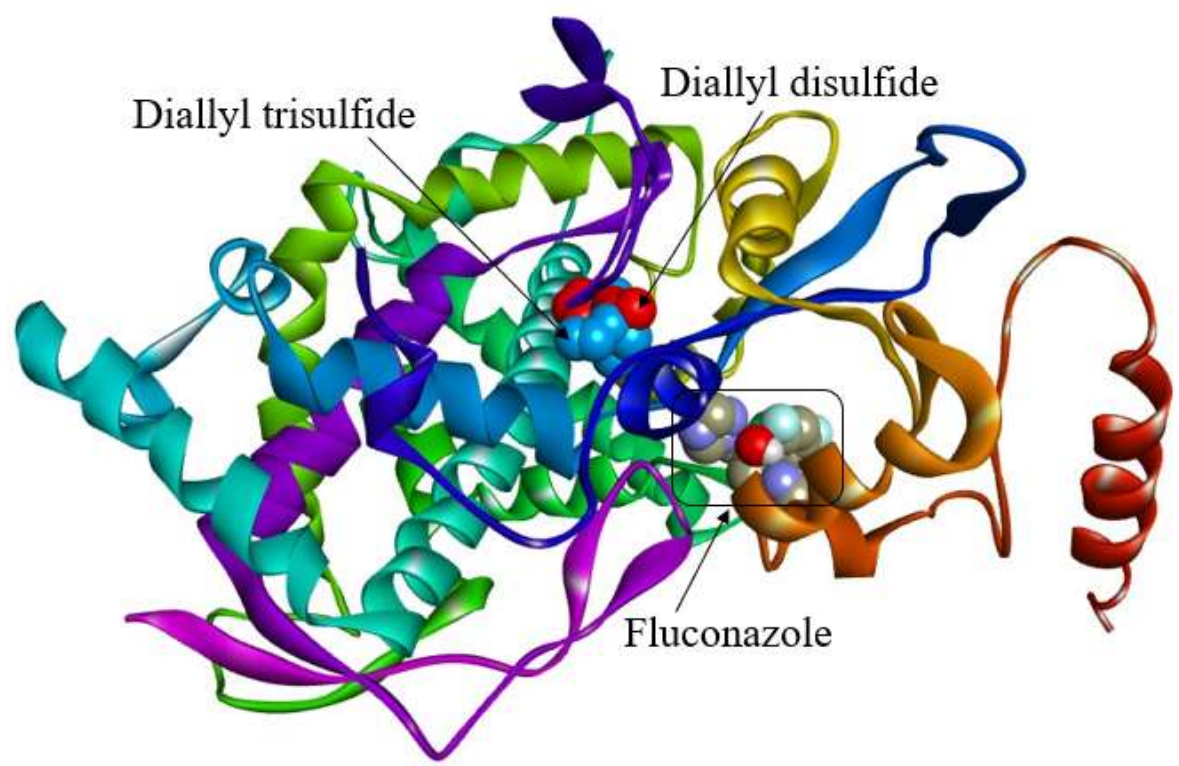

Source: Authors.

Figure 5. 2D maps of interactions between CYP51 complexes- Diallyl disulfide (A), CYP51- Diallyl trisulfide (B) and CYP51- Fluconazole (C).

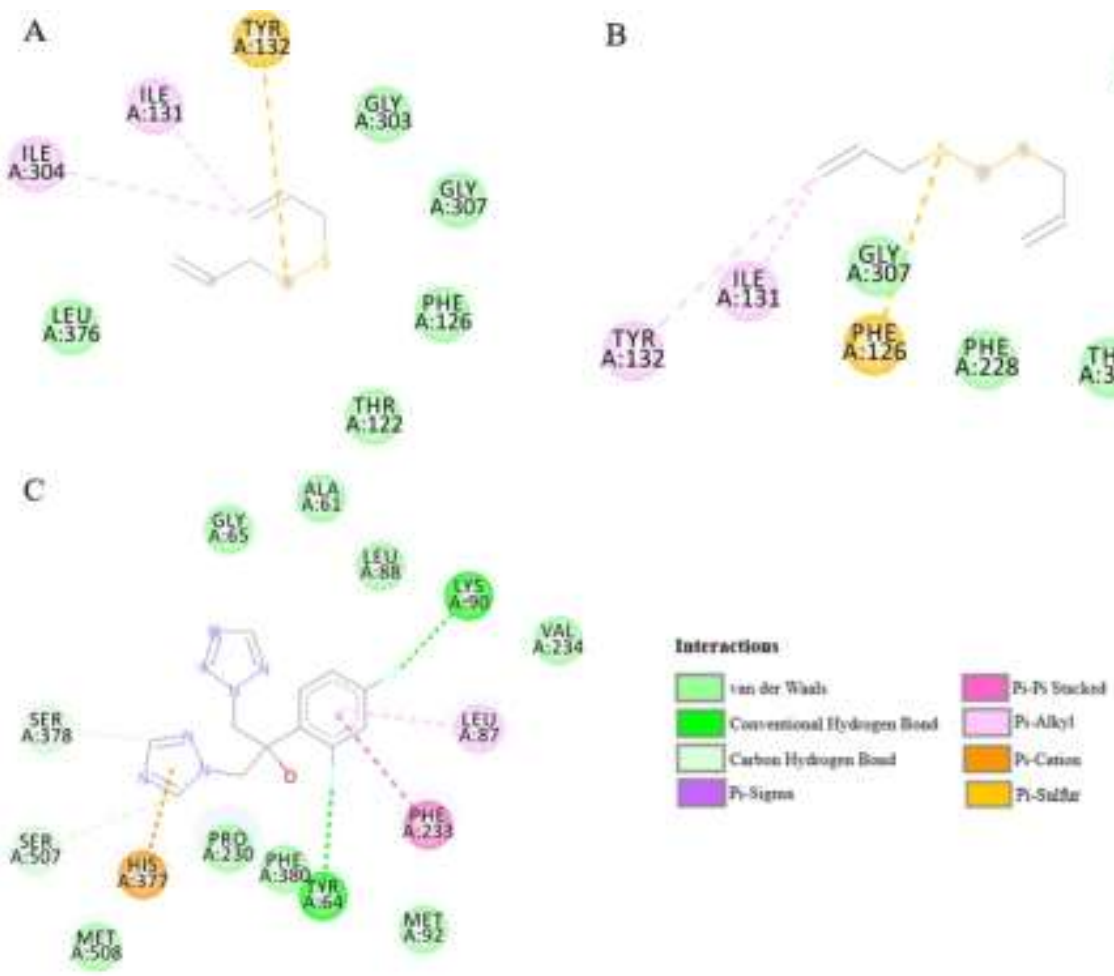

Source: Authors. 
Regarding the coupling to the active site of galantamine, it is possible to conclude that allicin is the molecule that has the greatest inhibitory potential, possibly being superior to galantamine (Figure 6). Putting in potential allicin> diallyl trisulfide> allyl methyl trisulfide. Diallyl disulfide was too far from the site, not interacting with any residue (Table 7).

Table 7. Comparative analysis of the interaction of binders with residues from the active site of Galantamine.

\begin{tabular}{lccrcc}
\hline $\begin{array}{l}\text { Acetylcholine } \\
\text { residues }\end{array}$ & Galanthamine & $\begin{array}{l}\text { Diallyl } \\
\text { disulfide }\end{array}$ & $\begin{array}{l}\text { Diallyl } \\
\text { trisulfide }\end{array}$ & $\begin{array}{l}\text { Allyl methyl } \\
\text { trisulfide }\end{array}$ & Allicin \\
\hline Trp86 & $3.8 \AA$ & - & 3.90 & 3.76 & 3.73 \\
\hline Gly120 & $4.0 \AA$ & - & & & 2.49 \\
\hline Gly121 & $4.1 \AA$ & - & & & 2.34 \\
\hline Gly122 & $4.1 \AA$ & - & & & 2.32 \\
\hline Ser203 & $3.4 \AA$ & - & & & 3.68 \\
\hline Phe295 & $3.4 \AA$ & - & & & \\
\hline Phe297 & $3.9 \AA$ & - & 3.62 & & \\
\hline Tyr337 & $3.3 \AA$ & - & 3.63 & & \\
\hline His447 & $3.1 \AA$ & - & & & \\
\hline
\end{tabular}

Hidrophobic interactions. Hydrogen bonds. Source: Authors.

Observing the energy criterion, the ideal would be less than $-6.00 \mathrm{kcal} / \mathrm{mol}$, as we can observe all the molecules were below the ideal, being an indication of low binding affinity, implying that a relatively high concentration of a ligand is necessary before the binding site is occupied to the maximum and the maximum physiological response to the ligand is reached. Highlighting that allicin showed the best affinity, followed by diallyl trisulfide (Table 8 ).

Table 8. Affinity Energy and RMSD between binders and acetylcholinesterase.

\begin{tabular}{lcc}
\hline Inhibitor & Affinity $(\boldsymbol{\Delta G})(\mathbf{k c a l} / \mathbf{m o l})$ & RMSD $(\AA)$ \\
\hline Diallyldisulfide & -3.7 & 1.406 \\
\hline Diallyltrisulfide & -4.1 & 1.703 \\
\hline Allyl methyl trisulfide & -3.3 & 1.915 \\
\hline Allicin & -4.5 & 1.194 \\
\hline
\end{tabular}

Source: Authors.

Khodavandi and collaborators (2010) used fluconazole as a standard antidepressant drug for comparison with allicin. The MICs of allicin and fluconazole against C. albicans ranged from 0.05 to 12 and 0.25 to $16 \mu \mathrm{g}$. $\mathrm{mL}^{-1}$, respectively, which is similar to the findings of previous reports (Ankri \& Mirelman, 1999; Khodavandi et al., 2010). All samples were sensitive to fluconazole and drug resistance was not observed.

Pointed out as one of the main causes of mortality in immunocompromised patients, fungal infections caused by Candida species have been gaining prominence (Sueth-Santiago et al., 2015). One of the main classes of antifungals, triazoles, 
such as itraconazole and fluconazole, have a broad spectrum of action against Candida species but have resistance problems (Silva et al., 2012; Colombo et al., 2013). In this context, it is necessary to search for new antifungal drugs, in isolation or in combination therapy (Guo 2008).

A target of azoles, the enzyme lanosterol 14 $\alpha$-demethylase (CYP51) plays a fundamental role in the process of biosynthesis of fungi ergosterol (Keniya et al., 2018; Sueth-Santiago et al., 2015; Hess \& Smentek 2013). The inhibition of CYP51 prevents the formation of ergosterol, weakening the fungal cell membrane (Silva et al., 2012; Colombo et al., 2013), being an important target in the search for new therapeutic strategies for the treatment of fungal infections.

Figure 6. Binding site of the compounds under study and 2D maps of interactions between complexes. Diallyldisulfide (A), Diallyl trisulfide (B), Allyl methyl trisulfide (C) e Allicin (D).

A
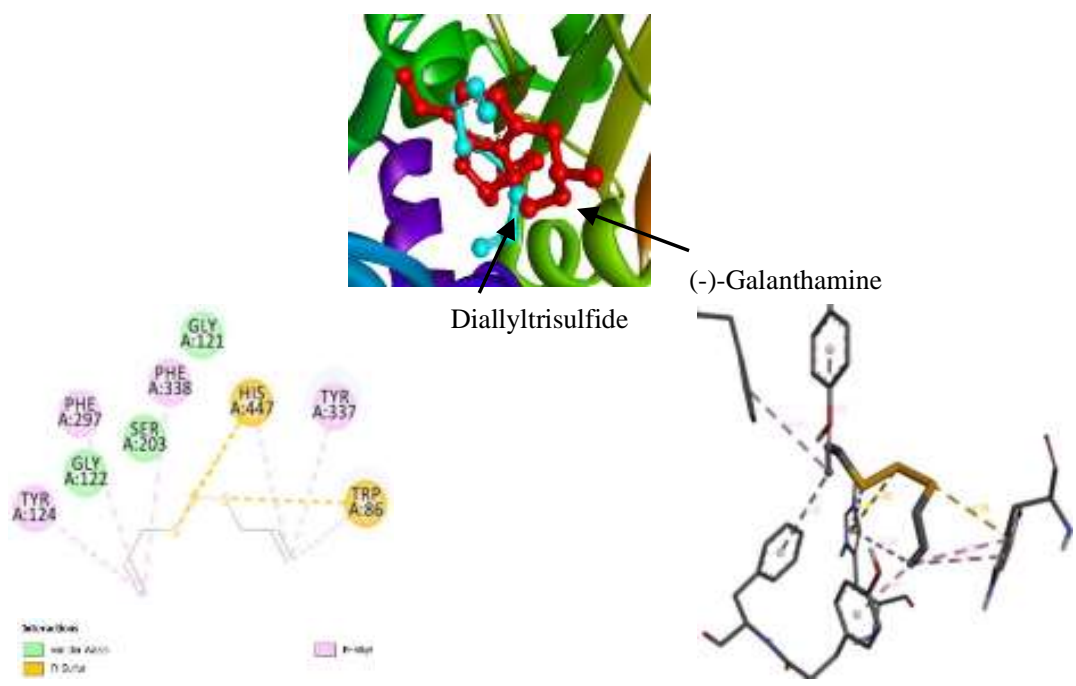

B
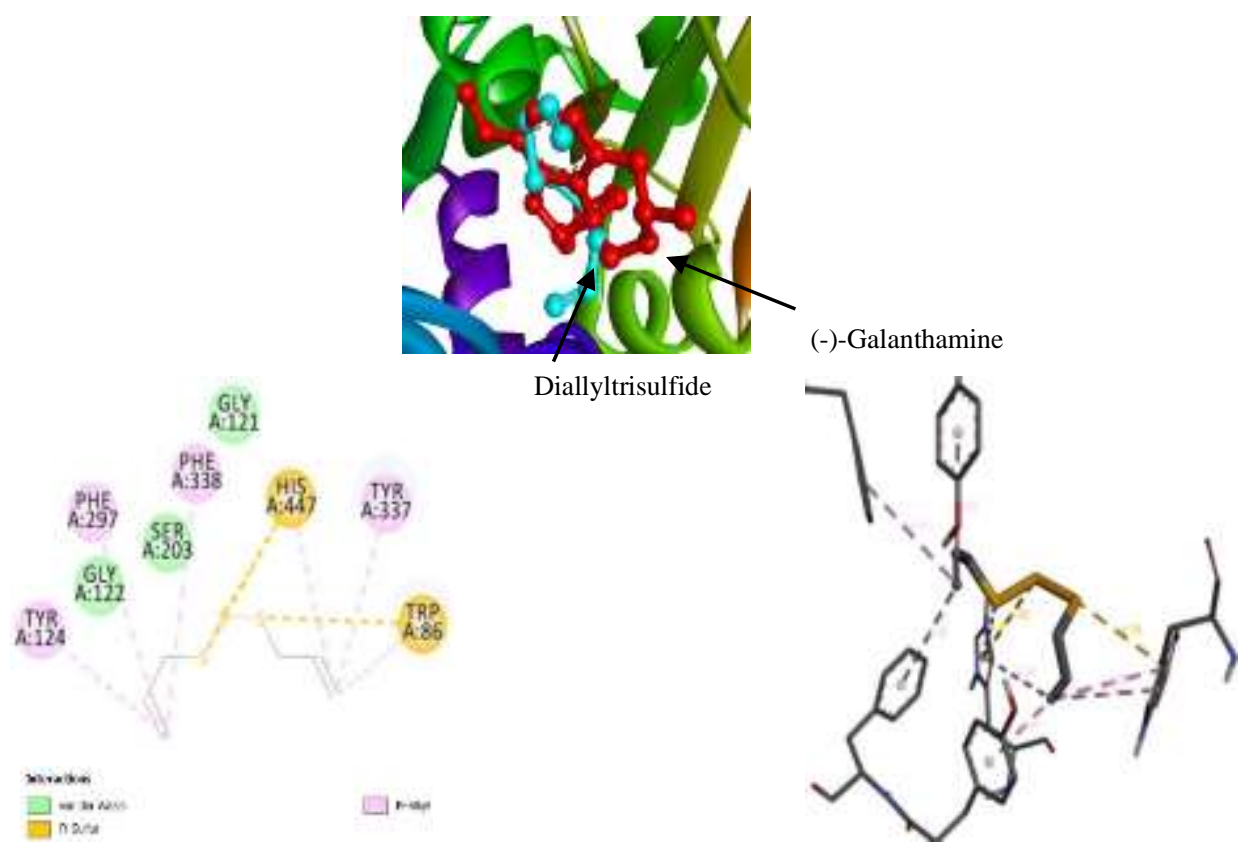
C

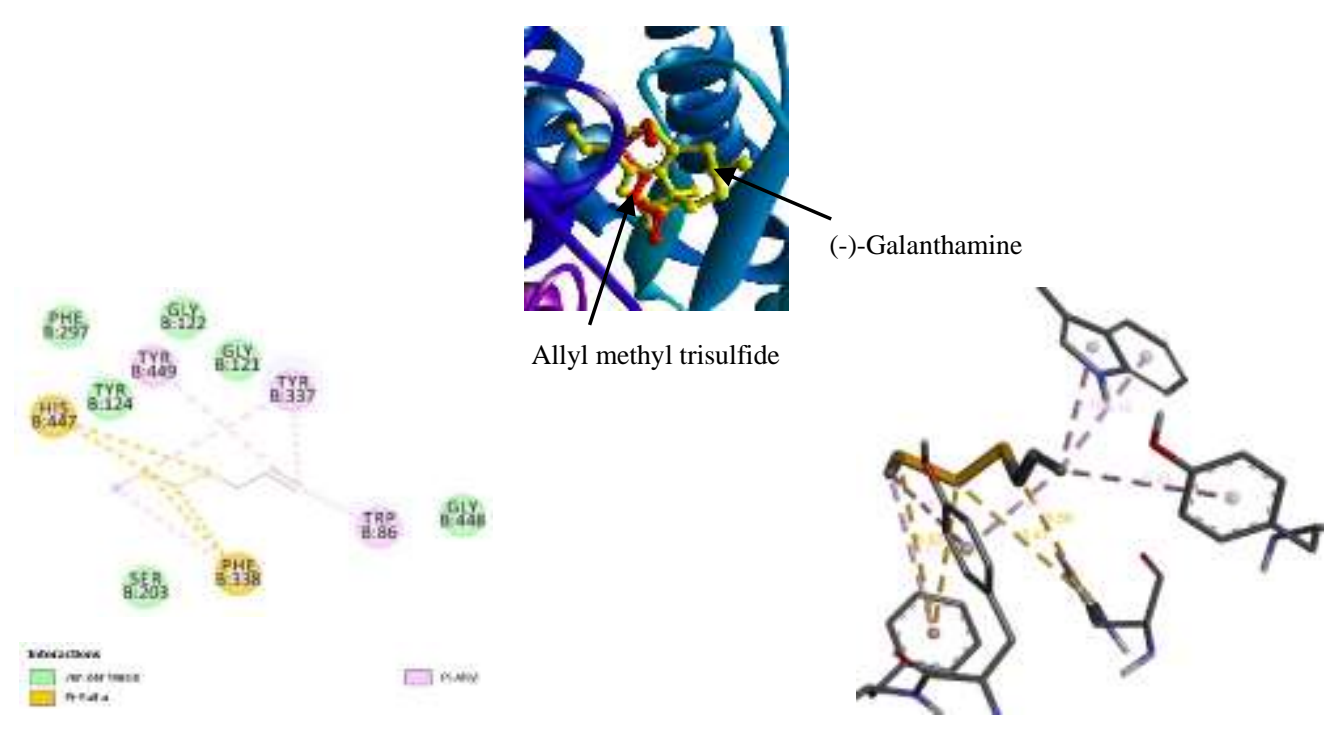

D

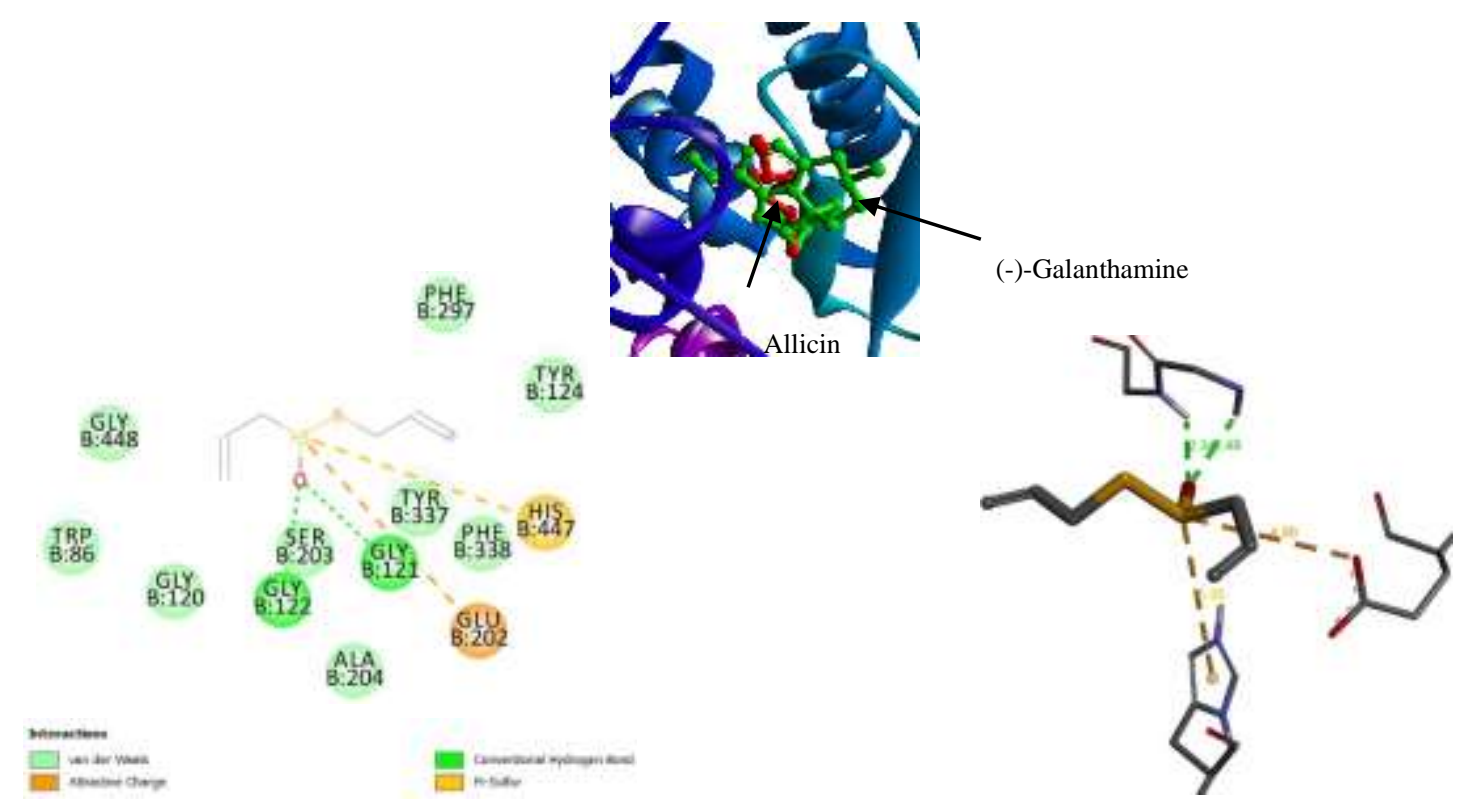

Source: Authors.

\section{Conclusion}

Based on the data obtained in this work, it was found that the essential oil of A. sativum has antifungal and antibiofilm activity on clinical isolates of C. albicans responsible for the development of pathologies in humans. Considering this way, as a possible biotechnological input, with therapeutic potential in the treatment of pathologies associated with formed biofilms. 
The interaction was synergistic, reducing the MIC values of the tested substances, modulating their antifungal actions against yeast strains. These results indicate that the essential oil potentiates the antifungal action of amphotericin B, suggesting a possible use of this compound in addition to the antifungal to treat infections. It also has antioxidant activity and inhibition of the enzyme acetylcholinesterase.

The major compounds of the essential oil of A. sativum, Diallyl disulfide and Diallyl trisulfide, coupled in the region of the itraconazole inhibitor catalytic site and in a region different from that occupied by fluconazole, making it possible to infer the potential use of these compounds synergistically with fluconazole as pharmacological tool in the treatment of fungal infections caused by Candida spp. However, the design of a new treatment model with different dosages of oil, as well as a combination with commercial antifungal drugs should be investigated. The molecular mechanisms of actions can be further investigated to determine their likely targets in C. albicans cells.

\section{References}

Aala, F., Yusuf, U., M., Khodavandi A \& Jamal F (2010) In vitro antifungal activity of allicin alone and in combination with two medications against six dermatophytic fungi. Afr J Microbiol Res 4: 380-385.

Almeida-Neto, F.,W.,Q., Silva, L., P., Ferreira, M., K., A., (2020). Characterization of the structural, spectroscopic, nonlinear optical, electronic properties and antioxidant activity of the N-\{4'-[(E)-3-(Fluorophenyl)-1-(phenyl)-prop-2-en-1-one] $\}$-acetamide. J. Mol. Struct, $1220,1-53$.

Alorainy., M. S. (2011). Evaluation of antimicrobial activity of garlic (Allium sativum) against E. coli O 157:H 7. Journal of Agriculture and Veterinary Science, 4, 149-157.

Amin., M \& Kapadnis, B, P. (2005). Heat stable antimicrobial activity of Allium ascalonicum against bacteria and fungi. Indian J Exp Biol; 43 (8):751-4.

An, M., Shen, H., Cao, Y., Zhang, J., Cai, Y., Wang, R., \& Jiang Y (2009) Allicin enhances the oxidative damage effect of amphotericin B against Candida albicans. Int J Antimicrob Ag 33: 258-263.

Ankri, S., \& Mirelman, D. (1999) Antimicrobial properties of allicin from garlic. Microbes Infect 1: $125-129$.

Armstrong-James, D., Brown, G. D., Netea, M.G., Zelante, T., Gresnigt, M., Van de Veerdonk, F., \& Levitz, S.M (2017). Immunotherapeutic approaches to treatment of fungal diseases. Lancet Infect Dis 17, 393-402.

Banerjee, S. K., Mukherjee, P. K., \& Maulik, S. K. (2003). Garlic as an antioxidant: The good, the bad and the ugly. Phytotherapy Research, $17,97-106$.

Behbahani, B., A., \& Fooladi, A., A., I. (2017) Evaluation of phytochemical analysis and antimicrobial activities Allium essential oil against the growth of some microbial pathogens. Microbial Pathogenesis. https://doi.org/10.1016/j.micpath.2017.11.055

Biovia, D. S. (2016). Dassault Systèmes BIOVIA, Discovery Studio Visualizer, v.17.2, Dassault Systèmes. J. Chem. Phys., 2000, 10.1016/00219991(74)90010-2.

Block, E., Naganathan, S., Putman, D., \& Zhao, S.-H. (1993). Organo-sulfur chemistry of garlic and onion: Recent results. Pure and Applied Chemistry, 65, $625-632$.

Borlinghaus, J., Albrecht, F., Gruhlke, M. C. H., Nwachukwu, I. D., \& Slusarenko, A. J. (2014). Allicin: Chemistry and biological properties. Molecules, 19, 12591-12618.

Capasso, A. (2013). Antioxidant action and therapeutic efficacy of Allium sativum L. Molecules, 18, 690-700.

Casella, S., Leonardi, M., Melai, B., Fratini, F., \& Pistelli L. (2012). The role of diallyl sulfides and dipropyl sulfides in the in vitro antimicrobial activity of the essential oil of garlic, Allium sativum L., and leek, Allium porrum L. Phytotherapy Research.

Chen, S., Shen, X., Cheng, S., Li, P., Du, J., Chang, Y., \& Meng, H. (2013). Evaluation of garlic cultivars for polyphenolic content and antioxidant properties. PLOS ONE, 8, e79730.

Clinical and Laboratory Standards Institute, 2008a. Reference Method for Broth Dilution Antifungal Susceptibility Testing of Yeasts (Approved Standard. Document M27. CLSI). Third ed. vol. M27-A3. Clinical and Laboratory Standards Institute, Wayne, PA.

Clinical and Laboratory Standards Institute, 2008b. Reference Method for Broth Dilution Antifungal Susceptibility Testing of Filamentous Fungi (Approved Standard. Document M38. CLSI). Second ed. vol. M38-A2. Clinical and Laboratory Standards Institute, Wayne, PA

Cohain, J., S (2010). Cases series: Symptomatic Group B Rev. Bras. Pl. Med., 6(3), 679-684, 2014. Streptococcus vaginitis treated with fresh garlic. Integrative Medicine, 9, 40-3.

Colombo, A., L., Guimarães, T., Camargo, L., F., A., Richtmann, R., Queiroz-Telles, F., Salles, M., J., C., Cunha, C., A., Yasuda, M., A., S., Moretti, M., L., \& Nuccii M. (2013) Brazilian guidelines for the management of candidiasis - a joint meeting report of three medical societies: Sociedade Brasileira de 
Infectologia, Sociedade Paulista de Infectologia and Sociedade Brasileira de Medicina Tropical. Brazilian J. Infect. Dis. 17, $283-312$. 10.1016/j.bjid.2013.02.001.

Eric, F., Pettersen, Thomas, D., Goddard, C., C., Huang, G., S., Couch, D., M., Greenblatt, E., C., Meng, T., E., F., (2004). UCSF Chimera - A visualization system for exploratory research and analysis. J. Comput. Chem., 25(13), 1605-1612, 10.1002/jcc.20084.

FAO (2013). Production and trade statistics. FAO.

Fasihzadeh, S., Lorigooini, Z., Jivad, N., (2016) Chemical constituents of Allium stipitatum regel 341 (persian shallot) essential oil. Der Pharmacia Lettre. 8:175-80.

Fontenelle, R. O. S.; Morais, S. M.; Brito, E. H. S.; Mendonça, M. R. K.; Brilhante, R. S. N.; Cordeiro, R. A. N.; Nascimento, N. R. F.; Sidrim, J. J. C.; \& Rocha, M. F. G. (2007) Chemical composition, toxicological aspects and antifungal activity of essential oil from Lippia sidoides Cham. Journal of Antimicrobial Chemotherapy, 59(5), 934-940.

Fontenelle, R. O. S., Morais, S. M., Brito, E. H. S., Brilhante, R. S. N., Cordeiro, R. A., Nascimento, N. R. F., Kerntopf, M. R., Sidrim, J. J. C., \& Rocha, M. F. G., (2008). Antifungal activity of essential oils of Croton species from the Brazilian Caatinga biome. J. Appl. Microbiol. 104, $1383-1390$.

Galdiero, E., Onofrio, V. D., Maione, A., Gambino, E., Gesuele, R., Menale, B., Ciaravolo, M., Carraturo., \& Guida, M. (2020) Allium ursinum and Allium oschaninii against Klebsiella pneumoniae and Candida albicans Mono- and Polymicrobic Biofilms in In Vitro Static and Dynamic Models. Microorganisms 27;8(3):336, 1-12.

Guo, N., Wu, X., Yu, L., Liu, J., Meng, R., Jin, J., Lu, H., Wang, X., Yan, S., \& Deng X (2010). In vitro and in vivo interactions between fluconazole and allicin against clinical isolates of fluconazoleresistant Candida albicans determined by alternative methods. FEMS Immunol Med Microbiol 58: 193-201.

Guo, Q., Sun, S., Yu. J., Li, Y., \& Cao, L. (2008) Synergistic activity of azoles with amiodarone against clinically resistant Candida albicans tested by chequerboard and time-kill methods," J. Med. Microbiol. 10.1099/jmm.0.47651-0.

Hess, A., \& Smentek, L., (2012) The concerted nature of the cyclization of squalene oxide to the protosterol cation. Angew. Chemie - Int. Ed.

Horníc `ková, J., Kubec, R., Cejpek, K., Velíšek, J., Ovesná, J., \& Stavelíková, H. (2010). Profiles of S-alk(en)ylcysteine sulfoxides in various garlic genotypes. Czech Journal of Food Sciences, 28(4), 298-308.

Imberty, K., D., Hardman, J., Carver, P., \& Perez S., (1991) Molecular modelling of protein-carbohydrate interactions. Docking of monosaccharides in the binding site of concanavalin A," Glycobiology, 10.1093/glycob/1.6.631.

Keniya, M., V., Sabherwal, M., Wilson, R., K., Woods, M., A, Sagatova, A., A., Tyndall, J., D., A., Monk, B., C., (2018) Crystal Structures of Full-Length Lanosterol 14 $\alpha$-Demethylases of Prominent Fungal Pathogens Candida albicans and Candida glabrata Provide Tools for Antifungal Discovery," Antimicrob. Agents Chemother. 10.1128/AAC.01134-18.

Khodavandi, A., Alizadeh, F., Aala, F., Sekawi, Z., \& Chong, P.P, (2010) In vitro investigation of antifungal activity of allicin alone and in combination with azoles against Candida species. Mycopathologia 169: 287-295.

Kumar, R., Chhatwal, S., Arora, S., Sharma, S., Singh, J., Singh, N., Khurana, A. (2013). Antihyperglycemic, antihyperlipidemic, anti-inflammatory and adenosine deaminase-lowering effects of garlic in patients with type 2 diabetes mellitus with obesity. Diabetes, Metabolic Syndrome and Obesity: Targets and Therapy, 6, 49-56.

Lanzotti, V., Scala, F., \& Bonanomi, G. (2014). Compounds from Allium species with cytotoxic and antimicrobial activity. Phytochemistry Reviews, 13, 769791.

Lemar, K., M., Passa, O., Aon, M., A., Cortassa, S., M"uller, C., T., Plummer, S., O’Rourke, B., \& Lloyd, D. (2005) Allyl alcohol and garlic (0) extract produce oxidative stress in Candida albicans. Microbiology 151: 3257-3265.

Lemar, K., M., Turner, M., P., \& Lloyd, D. (2002) Garlic (Allium sativum) as an anti-Candida agent: a comparison of the efficacy of fresh garlic and freezedried extracts. J Appl Microbiol 93: 398-405.

Li, G., Ma, X., Deng, L., Zhao, X., Wei, Y. Gao, Z., Jia, J, Xu, J., \& Sun, C. (2015) Fresh garlic extract enhances the antimicrobial activities of antibiotics on resistant strains in vitro. Jundishapur J Microbiol; 8: e14814. 10.5812/jjm.14814.

Li, W. R., Shi, Q., S., Dai, H., Q., Liang, Q., Xie, X., B., Huang, X., M., Zhao, G., Z., Zhang, L., X. (2016) Antifungal activity, kinetics and molecular mechanism of action of garlic oil against Candida albicans. Scientific Reports, 6:22805.

Li, W., R., Shi, Q., S., Dai, H., Q., Liang, Q., Xie, X., B., Huang, X., M., Zhao, G., Z., \& Zhang, L., X. (2016) Antifungal activity, kinetics and molecular mechanism of action of garlic oil against Candida albicans. Sci Rep 2016; 6: 22805. 10.1038/ srep22805

Lima, C., M., B., L., Freitas, F., I., S., Morais, L., C., S., L., \& Cavalcanti, M., G., S. Ultrastructural study on the morphological changes to male worms of Schistosoma mansoni after in vitro exposure to allicin. Revista da Sociedade Brasileira de Medicina Tropical, 44(3), 327-30, 10.1590/S003786822011005000023 .

Low, C., F., Chong, P., P., Yong, P., V., C., Lim, C., S., Y., Ahmad, Z., \& Othman, F., (2008) Inhibition of hyphae formation and SIR2 expression in Candida albicans treated with fresh Allium sativum (garlic) extract. J Appl Microbiol 105: 2169-2177.

Mantawy, M., M., Ali, H., F., \& Rizk, M., Z. (2011) Therapeutic Effects of Allium sativum and Allium cepa in Schistosoma mansoni experimental infection. Revista do Instituto de Medicina Tropical de São Paulo 2011; 53: 155-163. 
Medici, N., \& Poeta, M. (2015) New insight on the development on fungal vaccines: from immunity to recent challenges. Mem Inst Oswaldo Cruz. 110:966e73.

Milite, C., Amendola, G., Nocentini, A., Bua, S, Cipriano, A., Barresi, E., Feoli, A., Novellino, E., Settimo, F., Supuran, C., T., Castellano, S., Cosconati, S., \& Taliani, Sabrina (2019). Novel 2-substituted-benzimidazole-6-sulfonamides as carbonic anhydrase inhibitors: synthesis, biological evaluation against isoforms I, II, IX and XII and molecular docking studies,” J. Enzyme Inhib. Med. Chem., 2019, 10.1080/14756366.2019.1666836.

Miron, T., Bercovici, T., Rabinkov, A., Wilchek, M. \& Mirelman, D. (2004) [3H] Allicin: preparation and applications. Anal Biochem 331: 364-369.

Nami, S., Mohammadi, R., Vakili, M., Khezripour, K., Mirzael, H., \&Morovati, H., (2018) Fungal vaccines, mechanism of actions and immunology: a comprehensive review. Biomed Pharm; 109:333e44.

Sakagami, T., Kawano, T., Yamashita, K., Ymada, E., Fujino, N., Kaeriyama, M., Fukuda, Y., Nomura, N., Mitsuyama, J., Suematsu, H., Watanabe, H., Asai, N., Koizumi, Y., Yamagishi, Y., Mikamo, H. (2019) Antifungal susceptibility trend and analysis of resistance mechanism for Candida species isolated from bloodstream at a Japanese university hospital. J Infect Chemother 25, 34-40.

Schimmel, P., Tao, J., \& Hill, J. (1998) Aminoacyl tRNA synthetases as targets for new anti-infectives. FASEB J., 10.1096/fasebj.12.15.1599.

Shams-Ghahfarokhi, M., Shokoohamiri, M., R., Amirrajab, N., Moghadasi, B., \& Ghajari, A., Zeini, F., (2006) In vitro antifungal activities of Allium cepa, Allium sativum and ketoconazole against some pathogenic yeasts and dermatophytes. Fitoterapia. 77(4):321-3. 24.

Shields, R., K., Nguyen, M., H., Press, E., G., Kwa, A., L., Cheng, S., Du, C., \& Clancy, C., J. (2012) The presence of na FKS mutation rather than MIC is an independent risk factor for failure of echinocandin therapy among patients with invasive candidiasis due to Candida glabrata. Antimicrob. Agents Chemother. $56,4862-4869$.

Shityakov, S., \& Förster, C., (2014) In silico predictive model to determine vector-mediated transport properties for the blood-brain barrier choline transporter," Adv. Appl. Bioinforma. Chem., 7(1), 23-36, 10.2147/AABC.S63749.

Silva, J., L., Teixeira, R., N., V., Santos, D., I., P., \& Pessoa, J., O. (2012) Atividade antifúngica de extratos vegetais sobre o crescimento in vitro de fitopatógenos. Revista verde de agroecologia e desenvolvimento sustentável, 7(1), 80-6.

Silva, S., Negri, M., Henriques, M., Oliveira, R., D. Williams, W., \& Azeredo, J. (2012) Candida glabrata, Candida parapsilosis and Candida tropicalis: Biology, epidemiology, pathogenicity and antifungal resistance," FEMS Microbiology Reviews, 10.1111/j.1574-6976.2011.00278.x.

Song, J., Zhang, S., \& Lu, L. (2018) Fungal cytochrome P450 protein Cyp51: What we can learn from its evolution, regulons and Cyp51-based azole resistance. Fungal Biology Reviews, 32 (3), 131-142.

Stepanovic, S., Vukovic, D., Dakic, I., Savic, B., \& Svabic-Vlahovic, M. (200) A modified microtiter-plate test for quantification of staphylococcal biofilm formation, J. Microbiol. Methods 40 (2) 175-179.

Stewart, J., J., P., (2013) Optimization of parameters for semiempirical methods VI: More modifications to the NDDO approximations and re-optimization of parameters, J. Mol. Model. 10.1007/s00894-012-1667-x.

Sueth-Santiago, V., Franklim, T., N., Lopes, N., D., \& M. E. F. Lima. (2015) CYP51: Is it a good idea?," Rev. Virtual Quim., 7(2), 539-575, 10.5935/1984 6835.20150024

Trott, O,. \& Olson, A., J., (2009) AutoDock Vina: Improving the speed and accuracy of docking with a new scoring function, efficient optimization, and multithreading," J. Comput. Chem. 10.1002/jcc.21334.

Venturoso, L., R., Bacchi., L., M., A., Gavassoni, L., W., Conus, L., A., Pontim, B., C., A., \& Bergamin, A., C. (2011) Atividade antifúngica de extratos vegetais sobre o desenvolvimento de fitopatógenos. Summa Phytopathologica, 37(1), 18-23, 2011.

Yamada, Y., \& Azuma, K. (1977) Evaluation of the in vitro antifungal activity of allicin. Antimicrob Agents Ch 11: $743-749$.

Yusuf, D., Davis, A. M., Kleywegt, G. J., \& Schmitt, S. (2008) An alternative method for the evaluation of docking performance: RSR vs RMSD. J. Chem. Inf. Model., 48(7), 1411-1422. 10.1021/ci800084x.

Zainal, M., Zain, N., M., Amin, I., M., Ahmad, V., N. (2020) The antimicrobial and antibiofilme properties of allicin against Candida albicans and Staphylococcus aureus - A therapeutic potential for denture stomatitis. The Saudi Dental Journal. 